\title{
APLIKASI GAME PUZZLE GROW UP BERBASIS ANDROID
}

\author{
Siti Mu'afiyah', Nurul Fuad', Azza Abidatin B. ${ }^{3}$ \\ 1)Program Studi Teknik Informatika Universitas Islam Lamongan \\ 2) Dosen Fakultas Teknik Prodi Teknik Universitas Islam Lamongan \\ 3) Dosen Fakultas Teknik Prodi Teknik Universitas Islam Lamongan
}

E-mail : sitimuafiyah30@gmail.com ${ }^{1}$,nurulfuad23@gmail.com ${ }^{2}$, bettaliy.azza@yahoo.com ${ }^{3}$

\begin{abstract}
ABSTRAK
Aplikasi Game "Puzzle Grow Up” menggunakan bahasa HTML (Hypertext Markup Language) yang bisa digunakan pada perangkat bersistem Android dengan bantuan program Intel xdk. Tujuan penulisan ini untuk mempelajari, menganalisis, merancang dan mengimplementasikan aplikasi game "puzzle grow up" tersebut. Perangkat lunak yang dikembangkan dalam penyusunan aplikasi ini menggunakan HTML (Hypertext Markup Language) yang merupakan bahasa dasar untuk web yang memungkinkan menampilkan informasi dalam bentuk teks, grafiks, dan juga untuk menghubungkan antar tampilan web page. Hasil akhir dari penelitian ini adalah menghasilkan game sebagai sarana hiburan yang bisa meminimalisir kejenuhan seseorang terhadap pekerjaan yang melibatkan perangkat seperti handphone atau smartphone berbasis Android. Aplikasi ini berjalan di atas OS Android dengan Android minimal Kitkat.
\end{abstract}

Kata Kunci: Android, Game, HTML

\section{ABSTRACT}

"Puzzle Grow Up" game application uses HTML (Hypertext Markup Language) that can be used on Android-powered devices with the help of Intel xdk program. The purpose of this undergraduate thesis is to learn, analyze, design and implement "Puzzle Grow Up" game application. The software developed in the preparation of this application uses HTML (Hypertext Markup Language) which is the basic language for the web that allows displaying information in the form of text, chart, and also connecting between web pages. The result of this research is to create game as a means of entertainment that can minimize the boredom of a person to the job which involves devices such as mobile phones or smartphones based on Android. The application runs on Android OS with Android Kitkat as the minimum version.

Keywords: Android, Game, HTML

\section{PENDAHULUAN}

Pada bab pendahuluan ini akan diuraikan tentang latar belakang, rumusan masalah, tujuan penelitian, metodologi penelitian dalam skripsi yang berjudul Aplikasi Game Puzzle Grow Up Berbasis Android.

\subsection{Latar Belakang}

Game pada era ini telah menjadi sesuatu hal yang semakin digemari oleh masyarakat umu, dahulu kala game hanya dimainkan sebagai sarana pengisi waktu luang dan hiburan semata, namun sekarang fungsi game semakin bertambah luas, seperti sebagai sarana pembelajaran, sarana informasi dan lain sebagainya.

Game menjadi salah satu pilihan utama untuk mengisi waktu senggang setelah berakifitas. Banyak game yang bermanfaat namun ada juga beberapa game yang tidak layak dimainkan karena faktor kekerasan, pornografi, dan hal lain yang berbau negatif, tentu keuntungan dan kerugian bermain game kembali terletak pada orang memainkannya.
Perkembangan game dari dahulu hingga sekarang semakin meningkat. Dahulu game dimainkan secara langsung oleh manusia dengan objek permainannya, seperti bermain kelereng atau bermain karet. Sekarang dengan perkembangan teknologi, game mulai dimasukkan ke dalam platform yang lebih canggih seperti Play Station atau Video Game. Peminat game pun semakin meningkat dan ada di banyak kalangan, ada juga peminat game dengan platform yang lebih kecil dan mudah di bawa kemana-mana untuk dimainkan yaitu melalui mobile game. Peminat mobile game sekarang bisa memakai beragam sistem seperti Symbian, Apple IOS, Windows Phone serta Android.

Game dengan sistem android semakin banyak digemari, karna sekarang handphone bersistem android semakin banyak di pasaran dengan harga yang terjangkau oleh masyarakat umum. Terdapat banyak jenis game android yang tersedia di Play 
Store, terutama game pengasah otak untuk meningkatkan konsentrasi pemain. Oleh karena itu di buatlah skripsi tentang alternatif game pengasah otak untuk meningkatkan konsen trasi pemain yang berjudul "Aplikasi Game Puzzle Grow Up Berbasis Android".

\subsection{Rumusan Masalah}

Game Berdasarkan latar belakang di atas dapat dirumuskan masalah yang akan dibahas sebagai berikut :

1. Bagaimana cara membuat dan merancang aplikasi game puzzle grow up berbasis andorid?

2. Bagaimana cara memasang aplikasi game puzzle grow up ke dalam handphone yang bersistem android?

3. Bagaimana cara memainkan aplikasi game puzzle grow up berbasis android sesuai dengan aturan permainan?

4. Bagaimana aturan permainan yang terdapat dalam aplikasi game puzzle grow up berbasis android?

\subsection{Tujuan Penelitian}

Tujuan penelitian dalam aplikasi game puzzle grow up adalah sebagai berikut :

1. Untuk melatih otak pemain dalam menyelesaikan permainan game puzzle grow up berbasis android.

2. Untuk menjadi alternatif lain dalam bermain game android diantara game yang ada sekarang.

3. Untuk menjadi media hiburan pemain serta dapat merangsang otak untuk terus berpikir.

4. Untuk pengisi waktu luang yang tetap mempertahankan kinerja otak dalam berpikir.

\subsection{Metodologi Penilitian}

Dalam menyusun aplikasi game puzzle grow up berbasis android ini dilakukan beberapa penerapan metode penelitian untuk menyelesaikan permasalahan.

Metode penelitian yang digunakan dalam membangun sistem atau aplikasi ini melalui beberapa tahapan yang dibagi menjadi beberapa langkah yaitu:

1. Penelitian Kepustakaan

Pada tahap ini akan dilakukan studi literatur yang bertujuan untuk mengumpulkan, mempelajari serta menyeleksi bahan-bahan yang diperlukan untuk penulisan laporan skripsi ini.

2. Analisa Sistem

Pada tahap ini akan dilakukan analisis masalah yang dikaji serta mendefinisikan bahasanbahasan terhadap masalah tersebut, serta melakukan analisis terhadap kebutuhan perangkat aplikasi yang akan dibangun.

3. Perancangan Sistem
Pada tahap ini dilakukan perancangan suatu sistem aplikasi aplikasi android.

4. Implementasi Sistem

Pada tahap ini akan dilakukan pengkodean program untuk aplikasi android menggunakan perangkat notepad++ dan Intel XDK menggunakan bahasa html.

5. Dokumentasi Sistem

Pada tahap ini dilakukan pembuatan laporan naskah skripsi secara lengkap dari awal hingga akhir.

\section{TINJAUAN PUSTAKA}

$\mathrm{Bab}$ ini membahas tentang penjelasan landasan teori yang berisi berbagai konsep dasar dan teoriteori yang berkaitan dalam pembuatan Aplikasi Game Puzzle Grow Up Berbasis Android.

\subsection{Android}

Perkembangan android menurut Ardiansyah (2011), perkembangan android sampai saat ini mengalami kemajuan yang sangat pesat karena di dasari oleh kemudahan dalam pemakainya.

1. Android 1.1 Sistem Android yang dikenal dengan nama Android Alpha dan Android Beta ini pertama kali diperkenalkan pada tahun 2007 dan baru mulai diaplikasikan pada smartphone di awal Maret 2009. Sebagai cikal bakal OS Android, versi ini bisa dikatakan cukup berhasil menjadi inisiator kesuksesan besar Android.

2. Android 1.5 (Cupcake). Sesaat setelah mengaplikasikan sistem operasinya pada smartphone, pada Mei 2009 Android kembali merilis versi terbarunya yang diberi nama Android Cupcake. Android Cupcake menawarkan beragam kelebihan dibandingkan dengan versi versi terdahulunya, yakni fasilitas unggah video ke Youtube, headset bluetooth yang nirkabel serta tampilan keyboard dan gambar yang lebih atraktif.

3. Android 1.6 (Donut). Tipe Android yang satu ini diluncurkan hanya berselang 4 bulan setelah peluncuran saudara kandungnya, Android Cupcake. Android Donut telah mengusung keunggulan lainnya yakni tampilan indikator baterai, fasilitas zoom in zoom out, penggunaan koneksi CDMA serta beberapa keunggulan lainnya.

4. Android 2.0 / 2.1 (Eclair). Masih di tahun 2009, Android kembali meluncurkan teknologi terbarunya yang diberi nama Android Éclair. Era Android Éclair kemudian berhasil menarik para perusahaan gadget untuk mulai membuat gadget dengan sistem layar sentuh yang sebelumnya dianggap kurang user friendly bagi para pengguna smartphone.

5. Android 2.2 (Froyo singkatan dari Frozen Yoghurt). Android Froyo diluncurkan pada Mei 
2010, 5 bulan setelah peluncuran Android Éclair. Pada tipe Android yang satu ini, keinginan para pengguna smartphone untuk memiliki kapasitas memori eksternal berupa slot micro SD sudah dapat diwujudkan.

6. Android 2.3 (Ginger Bread). Si roti jahe yang diluncurkan pada penghujung tahun 2010 memiliki tampilan yang atraktif dan disertai dengan penambahan fitur-fitur seperti dual camera dan video call. Tak hanya itu saja, Ginger Bread juga fokus pada peningkatan kualitas dan grafis game berbasis Android.

7. Android 3.0/3.1 (Honeycomb). Android yang diluncurkan pada Mei 2011 ini dikhususkan bagi para pengguna tablet PC berbasis Android. User interface nya pun berbeda dengan smartphone Android. Spesifikasi hardware yang tinggi serta tampilan layar yang lebih besar membuat Honeycomb cocok diaplikasikan pada tablet PC.

8. Android 4.0 (Ice Cream Sandwich). Ice Cream Sandwich diluncurkan pada tahun yang sama dengan peluncuran Honeycomb. Banyak sekali fitur-fitur baru yang disematkan pada Android versi empat ini, diantaranya adalah fitur pendeteksi wajah, fitur yang memaksimalkan kualitas fotografi, kualitas cideo yang lebih baik serta resolusi dan grafis gambar yang sangat memuaskan.

9. Android 4.1 (Jelly Bean). Sistem Android yang satu ini memberikan support pada fitur on screen keyboard yang membuat kegiatan mengetik menjadi lebih cepat, mudah dan responsif. Salah satu smartphone keren yang mengusung Android Jelly Bean adalah Google Nexus 7 yang diprakarsai oleh perusahaan ASUS.

10. Android 4.4 (Kitkat). Android Kitkat merupakan versi Android terbaru yang diluncurkan pada bulan September 2013. Penggunaan nama Kitkat menjadi suatu kejutan bagi para pecinta Android, karena nama Kitkat merupakan salah satu nama snack wafer yang populer di dunia. Penggunaan nama ini juga membuat tipe Android ini semakin mudah diingat orang.

11. Android 5 (Lolipop). Fitur-fitur pada Android Lollipop merupakan desain ulang dari user interface yang dibangun sekitar bahasa desain responsif yang disebut dengan "material design”. Perubahan lainnya yaitu perbaikan pada pemberitahuan / notifikasi, yang bisa di akses dari lockscreen dan dapat ditampilkan tanpa aplikasi tambahan sebagai top-of-the-screen banner.

\subsection{HTML5}

Menurut Hidayatullah dan Kawistara (2014, h. 45-47), HTML5 adalah standar baru dari HTML5, versi HTML sebelumnya yaitu HTML 4.01 muncul pada tahun 1999. Internet mengalami perubahan yang sangat signifikan sejak saat itu sampai sekarang. HTML5 didesain untuk memnuhi hampir semua kebutuhan user tanpa plugin tambahan. Kebutuhan-kebutuhan tersebut antara lain menampilkan animasi menjalankan aplikasi, memutar musik dan film.

Ada beberapa aturan yang coba diterapkan dalam versi baru HTML ini:

1. Fitur baru harus berbariskan HTML, CSS, DOM dan JavaScript.

2. Penggunaan pligin eksternal (seperti Flash) harus dikurangi.

3. Penanganan error harus lebih mudah.

4. Scripting harus diganti dengan lebih banyak markup.

5. HTML5 harus device-dependent.

6. Proses pengembangannya harus bisa dilihat oleh public.

Elemen-elemen yang dihilangkan di HTML5 dari elemen pada HTML 4.01 adalah sebagai berikut:

1. <acronym>

2. <applet>

3. <big>

4. <center >

5. $<$ dir $>$

6. <font $>$

7. <frame>

8. 〈frameset>

9. <noframes>

10. $\langle$ strike >

11. $\langle\mathrm{tt}\rangle$

\section{ANALISA DAN PERANCANGAN SISTEM}

Bab ini berisi pemaparan analisa-analisa data yang dapat membantu pembuatan aplikasi. Hasil dari analisia tersebut digunakan untuk melakukan perancangan struktur data, struktur menu dan perancangan antarmuka.

\subsection{Use Case Diagram}

Berikut ini adalah alur use case diagram aplikasi game puzzle grow up berbasis android:

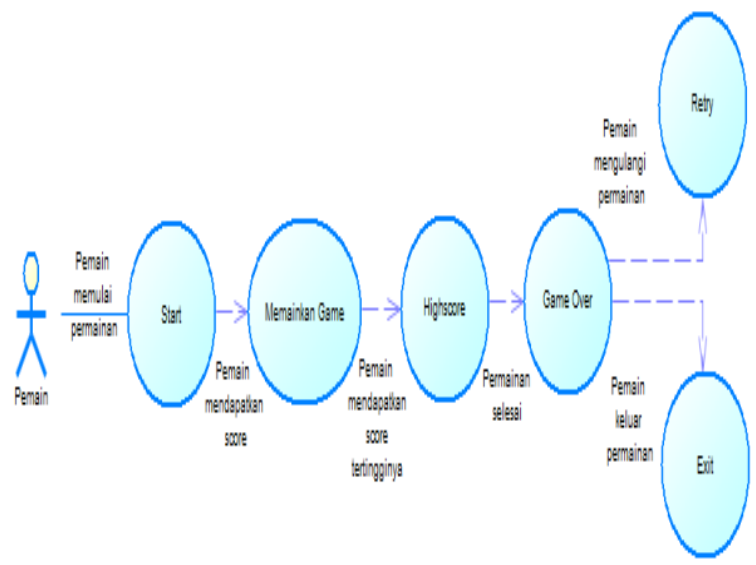

Gambar 3.1 Use Case Diagram 
Aktor disini adalah pemain yang memainkan aplikasi game puzzle grow up. Pemain membuka aplikasi game dan memulai permainan, untuk permulaan akan muncul beberapa gambar bayi di kotak-kotak yang telah disediakan secara acak. Permainan dimulai, pemain menyatukan gambar yang sama yaitu gambar, bayi, balita, anak-anak, tk, sd, smp, sma, mahasiswa, dewasa dan tua menjadi satu dan berubah menjadi gambar di atasnya sesuai dengan urutannya dan pemain akan mendapatkan score, bila gambar berbeda maka gambar hanya akan berdampingan saja tapi tidak bersatu dan pemain tidak mendapatkan score dari pergeseran game yang dilakukannya.

Apabila score telah melewati highscore sebelumnya, maka akan menjadi highscore yang baru tapi bila tidak melewati highscore sebelumnya maka highscore akan tetap. Permainan bisa dimulai kembali dengan memilih menu retry atau permainan selesai bila permainan dikeluarkan.

\subsection{Activity Diagram}

Berikut ini adalah alur use case diagram yang akan diterapkan pada aplikasi game puzzle grow up berbasis android:

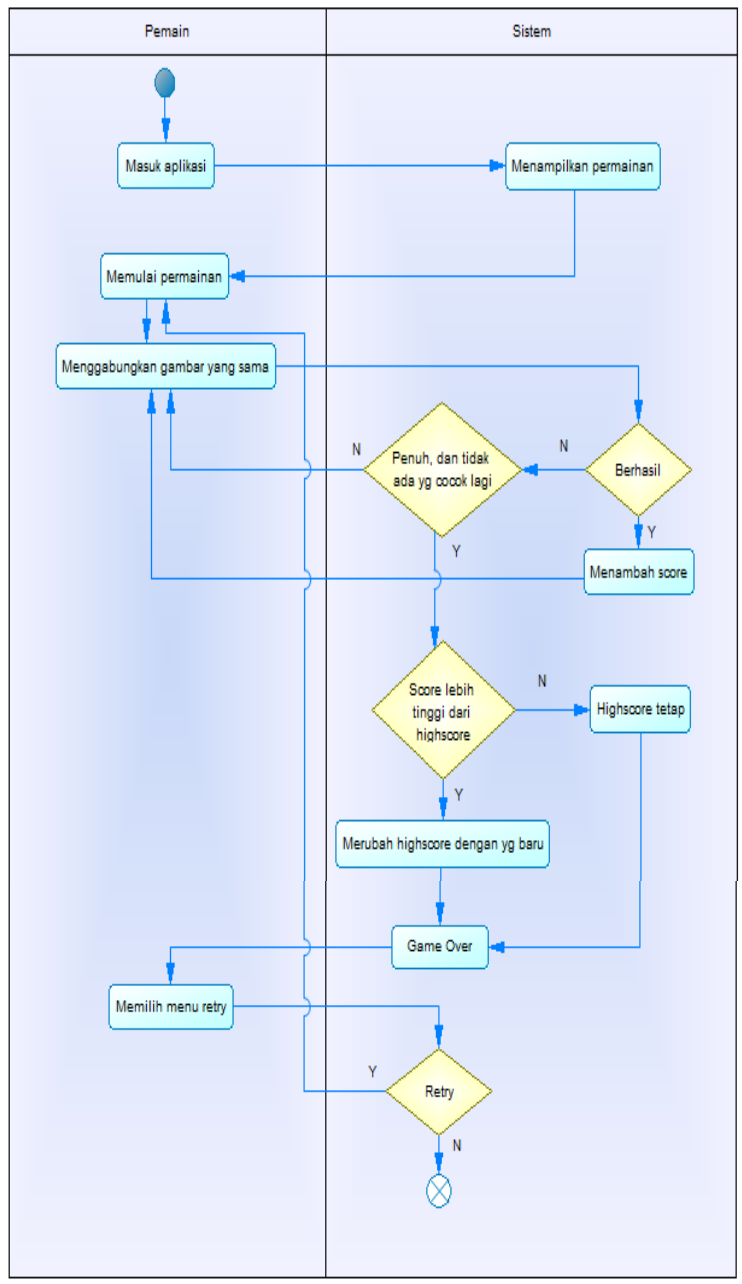

Gambar 3.2 Activity Diagram
Pemain masuk ke aplikasi game puzzle grow up lalu sistem menampilkan interface permainan, pemain memulai permainan dengan menggabungkan gambar yang sama, jika berhasil maka pemain mendapatkan score dan pemain menggabungkan gambar kembali, jika gagal tapi kotak masih belum penuh dan masih ada gambar yang bisa digabungkan.

Maka pemain masih bisa melanjutkan permainan dengan menggabungkan gambar kembali, tapi jika kotak sudah penuh dan tidak ada gambar yang bisa digabungkan, maka score yang telah didapatkan bila melebihi highscore sebelumnya, highscore diganti dengan score yang baru, bila score tidak melebihi highscore maka highscore akan tetap, permainan selesai.

\subsection{Sequence Diagram}

Berikut ini adalah alur use case diagram aplikasi game puzzle grow up berbasis android:

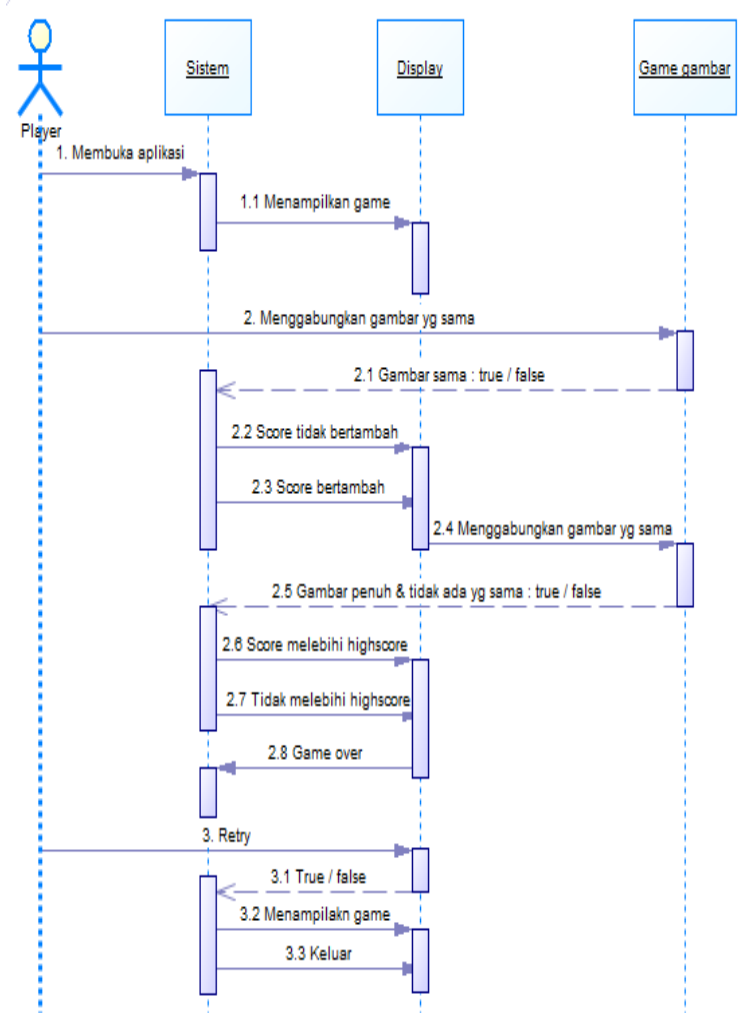

Gambar 3.3 Sequence Diagram

Player membuka aplikasi dan sistem menampilkan game display. Player menggabungkan gambar yang sama, bila gambar sama maka score bertambah tapi bila gambar tidak sama maka score tidak bertambah.

Apabila player menggabungkan gambar yang sama dan gambar penuh serta tidak ada yang sama maka permainan selesai, jika score melebihi highscore maka highscore diganti dengan score yang baru tapi jika score tidak melebihi highscore maka highscore tetap. 
Player bisa mengulang permainan kembali dengan menekan pilihan retry, maka permainan bisa dimainkan kembali tapi bila tidak maka aplikasi game keluar.

\subsection{Perancangan Antarmuka Atau Interface}

Berikut ini adalah rancangan antarmuka atau interface pada aplikasi game puzzle grow up berbasis android:

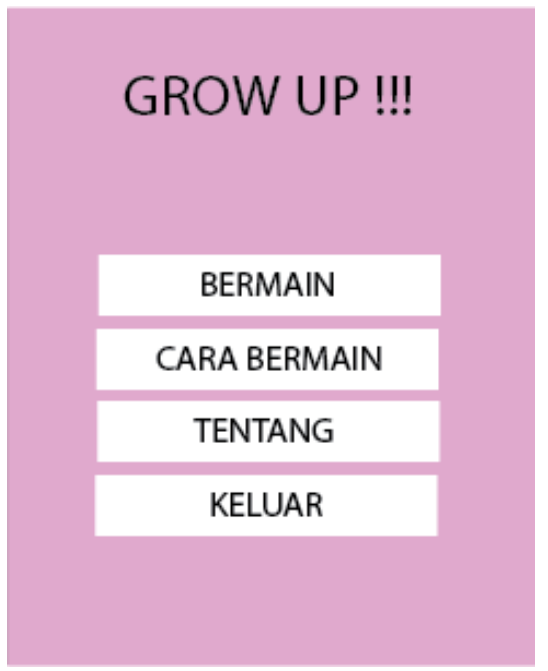

Gambar 3.4 Interface Menu Game

Game ketika dibuka akan memunculkan menu dari permainan, yaitu menu bermain, cara bermain, tentang dan keluar, dimana menu akan memunculkan isi sesuai dengan menu yang dipilih, pada menu bermain akan memunculkan permainan.

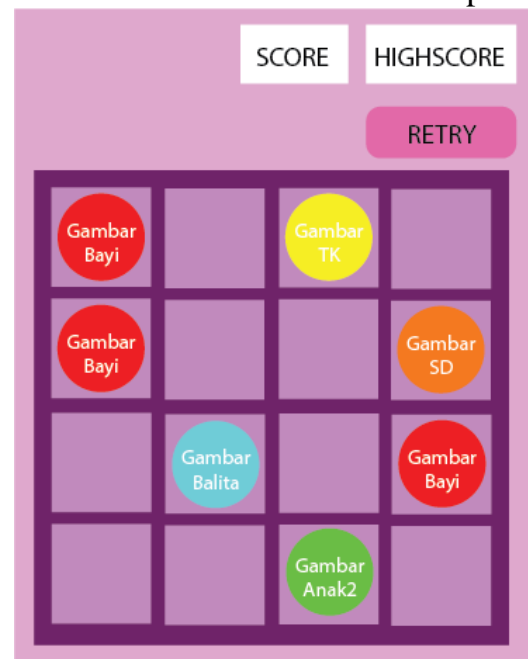

Gambar 3.5 Interface Game

Game berisi kolom score, highscore, tombol retry dan papan permainan yang nantinya akan muncul gambar-gambar perkembangan manusia dari bayi, balita, anak-anak, tk, sd, smp, sma, mahasiswa, dewasa dan tua. Dalam permainan game grow up ini nantinya setiap gambar yang sama bisa digabungkan menjadi satu menjadi gambar yang berada di atasnya dan memiliki score tersendiri seperti pada tabel berikut ini.
Tabel 3.1 Nilai Score Gambar

\begin{tabular}{|c|l|l|}
\hline No & Nama Gambar & Score \\
\hline 01. & Bayi & - \\
\hline 02. & Balita & 4 \\
\hline 03. & Anak-anak & 8 \\
\hline 04. & TK & 16 \\
\hline 05. & SD & 32 \\
\hline 06. & SMP & 64 \\
\hline 07. & SMA & 128 \\
\hline 08. & Mahasiswa & 256 \\
\hline 09. & Dewasa & 512 \\
\hline 10. & Tua & 1024 \\
\hline 11. & Piala & 2048 \\
\hline
\end{tabular}

Ketika gambar bayi dengan bayi digabungkan maka akan berubah menjadi gambar balita dan score akan bertambah 4, gambar balita dengan balita digabungkan maka kan berubah menjadi gambar anak-anak dan score akan bertambah 8, begitu seterusnya sampai gambar tua lalu piala.

\subsection{Aturan Permainan}

Aturan permainan adalah menggabungkan gambar-gambar menjadi gambar perkembangan manusia yang lebih tinggi.

Dengan menggeser bidang permainan ke arah atas, bawah, kanan atau kiri. Yang boleh digabung hanyalah kotak-kotak yang bergambar sama dan berada pada posisi yang bersisian samping kanan, kiri, atas dan bawah.

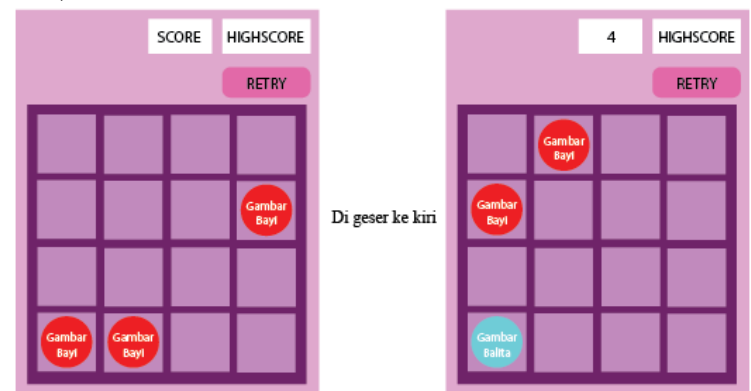

Gambar 3.6 Contoh Aturan Permainan

Contoh pada gambar 3.5 posisi awal gambar pertama (sebelah kiri), lalu digeser ke arah kiri, maka posisinya akan menjadi gambar kedua (sebelah kanan). Jika terdapat tiga kotak bersisian yang bergambar sama, maka yang digabung adalah dua pasang yang pertama.

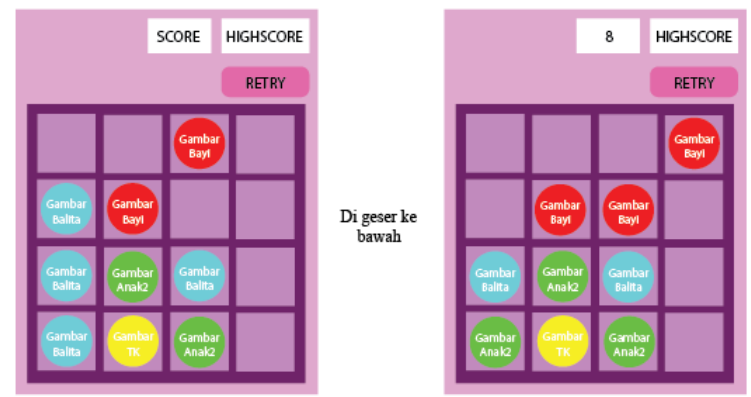

Gambar 3.7 Contoh Aturan Permainan kedua 
Pada gambar 3.7, jika posisi pertama di geser ke arah bawah, maka kedua gambar balita yang berada di kiri bawah akan tergabung menjadi gambar anakanak. Pada setiap pergeseran, akan muncul satu kotak gambar bayi atau balita dengan posisi acak di tempat yang masih kosong dan tidak menabrak gambar yang digeser.

Permainan dilanjutkan seperti itu, hingga nanti semua kotak terisi dan gambar tidak ada yang sama di setiap masing-masing sisi yang berdampingan.

\section{PEMBAHASAN}

Bab ini merupakan paparan implementasi dan analisis hasil uji coba program. Memaparkan hasilhasil dari tahapan penelitian, tahap analisis desain, implementasi desain, hasil testing dan juga implementasinya.

\subsection{Implementasi}

Tahap implementasi sistem merupakan tahap penerjemah perancangan berdasarkan hasil analisis ke dalam suatu bahasa pemrograman tertentu serta penerapan perangkat lunak yang dibangun pada lingkungan yang sesungguhnya. Adapun pembahasan implementasi terdiri dari perangkat lunak pembangun, perangkat keras pembangun, dan implementasi antar muka.

Berikut ini adalah objek dari aplikasi game yang akan dimasukkan ke dalam sistem:

1. Gambar Bayi

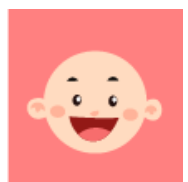

\section{Gambar 4.1 Gambar Bayi}

Ketika memainkan aplikasi game puzzle grow up ini dan menggabungkan 2 gambar 4.1 maka pemain akan mendapatkan tambahan nilai score yaitu 4 dan gambar 4.1 akan berubah menjai gambar 4.2 yaitu gambar Balita.

2. Gambar Balita

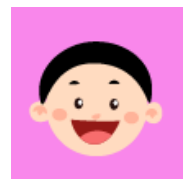

\section{Gambar 4.2 Gambar Balita}

Ketika memainkan aplikasi game puzzle grow ini dan menggabungkan 2 gambar 4.2 maka pemain akan mendapatkan tambahan nilai score yaitu 8 dan gambar 4.2 akan berubah menjai gambar 4.3 yaitu gambar Anak-anak.

3. Gambar Anak-anak

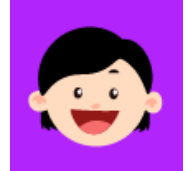

Gambar 4.3 Gambar Anak-anak
Ketika memainkan aplikasi game puzzle grow ini dan menggabungkan 2 gambar 4.3 maka pemain akan mendapatkan tambahan nilai score yaitu 16 dan gambar 4.3 akan berubah menjai gambar 4.4 yaitu gambar TK yang identik dengan topi khas pada anak TK.

4. Gambar TK

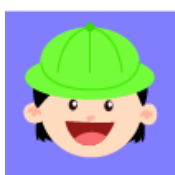

\section{Gambar 4.4 Gambar TK}

Ketika memainkan aplikasi game puzzle grow ini dan menggabungkan 2 gambar 4.4 maka pemain akan mendapatkan tambahan nilai score yaitu 32 dan gambar 4.4 akan berubah menjai gambar 4.5 yaitu gambar SD.

5. Gambar SD

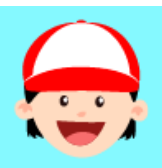

\section{Gambar 4.5 Gambar SD}

Ketika memainkan aplikasi game puzzle grow ini dan menggabungkan 2 gambar 4.5 maka pemain akan mendapatkan tambahan nilai score yaitu 64 dan gambar 4.5 akan berubah menjai gambar 4.6 yaitu gambar SMP.

6. Gambar SMP

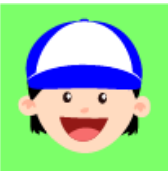

\section{Gambar 4.6 Gambar SMP}

Ketika memainkan aplikasi game puzzle grow ini dan menggabungkan 2 gambar 4.6 maka pemain akan mendapatkan tambahan nilai score yaitu 128 dan gambar 4.6 akan berubah menjai gambar 4.7 yaitu gambar SMA.

7. Gambar SMA

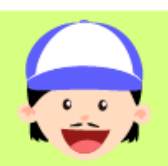

Gambar 4.7 Gambar SMA

Ketika memainkan aplikasi game puzzle grow ini dan menggabungkan 2 gambar 4.7 maka pemain akan mendapatkan tambahan nilai score yaitu 256 dan gambar 4.7 akan berubah menjai gambar 4.8 yaitu gambar Mahasiswa.

8. Gambar Mahasiswa

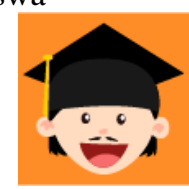

Gambar 4.8 Gambar Mahasiswa 
Ketika memainkan aplikasi game puzzle grow ini dan menggabungkan 2 gambar 4.8 maka pemain akan mendapatkan tambahan nilai score yaitu 512 dan gambar 4.8 akan berubah menjai gambar 4.9 yaitu gambar Dewasa.

9. Gambar Dewasa

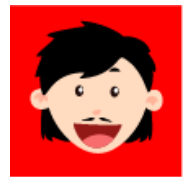

Gambar 4.9 Gambar Dewasa

Ketika memainkan aplikasi game puzzle grow ini dan menggabungkan 2 gambar 4.9 maka pemain akan mendapatkan tambahan nilai score yaitu 1024 dan gambar 4.9 akan berubah menjai gambar 4.10 yaitu gambar Tua.

10. Gambar Tua

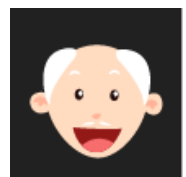

Gambar 4.10 Gambar Tua

Ketika memainkan aplikasi game puzzle grow ini dan menggabungkan 2 gambar 4.10 maka pemain akan mendapatkan tambahan nilai score yaitu 2048 dan gambar 4.10 akan berubah menjai gambar 4.11 yaitu gambar Piala.

11. Gambar Piala

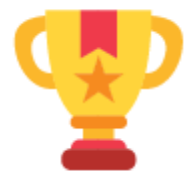

\section{Gambar 4.11 Gambar Piala}

Ketika memainkan aplikasi game puzzle grow ini dan sudah bisa sampai pada penggabungan terakhir yaitu 2 gambar 4.10 yaitu gambar tua menjadi gambar 4.11 berupa gambar piala, maka penggabungan gambar antara gambar 4.11 sudah tidak bisa lagi, dan pemain berupaya untuk bisa mengumpulkan gambar 4.11 sebanyak-banyaknya karna gambar 4.11 adalah gambar tertinggi. 12. Header

\section{GROWUPI!I}

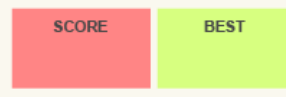

Gambar 4.12 Gambar Header

Ketika memainkan aplikasi game puzzle grow ini, menu tampilan atas atau header nya adalah seperti gambar 4.12. Terdapat tulisan GROW UP !!! sebagai nama dari game ini, di sebelah kanannya terdapat kolom score untuk melihat setiap score yang diperoleh pemain, di sebelah kanannya lagi terdapat kolom best yaitu kolom yang berisi nilai score tertinggi.
Berikut ini adalah implementasi aplikasi game puzzle grow up berbasis android :

\section{GROW UP !!!}

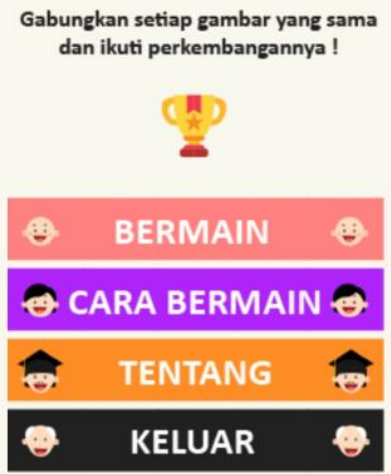

Gambar 4.13 Tampilan Menu Game

Pada gambar 4.13 merupakan tampilan awal ketika membuka game, terdapat judul dari game grow up lalu dibawahnya terdapat beberapa menu dalam game, yaitu menu bermain, cara bermain, tentang dan keluar. Ketika menu bermain dipilih akan menampilkan permainan.

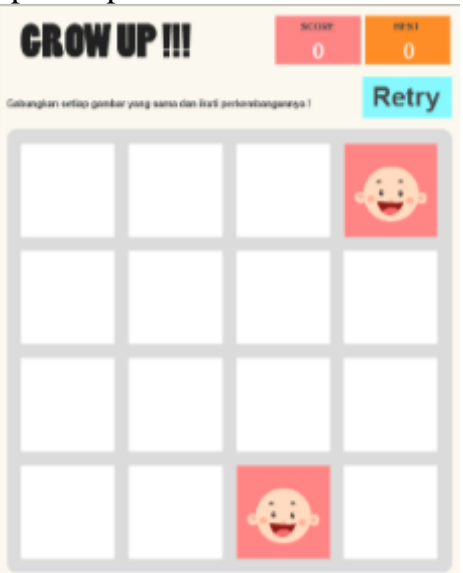

Gambar 4.14 Tampilan Game

Pada gambar 4.14 merupakan tampilan game yang diinginkan ketika digabungkan semua objek gambar yang telah dibuat sebelumnya yaitu dari gambar 4.1 sampai gambar 4.12 .

Game ini dibuat menggunakan program Intel XDK yang secara gratis bisa di download langsung tanpa biaya sepeserpun, banyak kemudahan yang disuguhkan oleh intel XDK untuk para developer android yang ingin membuat suatu aplikasi android. Terlebih lagi intel XDK menggunakn fitur HTML untuk membuat aplikasi androidnya, jadi untuk yang bisa menggunakan bahasa HTML dan ingin membuat aplikasi android maka intel XDK adalah salah satu program yang cocok untuk di coba.

Aplikasi game puzzle grow up berbasis android ini dirancang dan dibuat menggunakan program intel XDK yang menggunakan bahasa web yakni html 
dan javacript, dengan dibuatnya aplikasi game ini diharapkan menjadi salah satu pilihan dari berbagai permainan yang sudah ada di luar sana baik yang sudah ada di playstore atau yang tidak. Dengan semakin banyaknya aplikasi game maka para penikmat game juga akan dimanjakan dengan gamegame yang sesuai selera mereka masing-masing.

Aplikasi game puzzle grow up berbasis android ini bisa dimainkan dari kalangan anak berusia 5 tahun sampai orang yang sudah tua sekalipun, dengan kemudahan cara memainkan game dan dengan tampilan gambar dari perkembangan manusia mulai bayi sampai orang tua hingga piala sebagai apresiasi buat mereka yang sampai bisa menggabungkan gambar orang tua. Diharapkan aplikasi game ini dapat sebagai sarana hiburan yang cocok dan dapat diterima di kalangan masyarakat.

\section{KESIMPULAN}

Dari hasil kegiatan penelitian yang dilakukan, mulai dari melakukan rangkaian perancanganperancangan, desain, pengodingan, implementasi dan pengujian aplikasi game puzzle grow up ini, maka dari semua proses tersebut dapat disimpulkan:

1. Aplikasi game puzzle grow up ini dirancang menggunakan aplikasi power designer yang menggunakan metode Unified Model Language, dengan perancangan berupa usecase diagram, activity diagram dan sequence diagram sehingga pemahaman aplikasi game ini bisa dengan mudah di pahami.

2. Aplikasi game puzzle grow up ini dibuat menggunakan program intel XDK yang menggunakan bahasa web yakni html dan javascript, jadi yang bisa menggunakan bahasa web dan masih belum bisa menggunakan bahasa android, bisa menggunakan program intel XDK.

3. Dengan dibuatnya aplikasi game puzzle grow up ini bisa menjadi salah satu pilihan untuk penikmat game terutama game android yang sekarang sudah banyak sekali genre-genre aplikasi game baik yang ada di playstore mauppun yang tidak ada di playstore.

4. Dengan dibuatnya aplikasi game puzzle grow up ini bisa menjadi saran hiburan baik untuk anak kecil minimal lima tahun sampai orang tua sekalipun.

\section{PUSTAKA}

Ardiansyah, Firdan. 2011. Pengenalan Dasar Android Programming. Depok: Biraynara.

Fauzul, Jefri. 2015. Mengenal Intel XDK, Software Multi Platform Untuk Pengembang Aplikasi Mobile, (Online), (http://bacolah.com/691/, diakses 13 Maret 2016).

Fauzy, Rizky. 2013. Pengertian, sejarah, jenis-jenis tentang game, (Online), (http://game- savero.blogspot.co.id/2013/05/pengertiansejarahj enis-jenis-tentang.html, diakses 12 Maret 2016).

Fowler, Martin. 2004. UML Ditilled Edisi 3. Yogyakarta: Andi.

Hidayatullah dan Kawistara. 2014. Pemrograman Web. Bandung: Informatika Bandung.

Riyanto. 2011. Sistem Infromasi Penjualan dengan PHP dan MySQL. Yogyakarta: Gava Media.

Wikipedia. 2016. Android (Sistem Operasi), (Online), (https://id.wikipedia.org/wiki/Android_ (sistem_operasi), diakses 10 Maret 2016).

Wikipedia. 2015. HTML5, (Online), (https://id.wikipedia.org/wiki/HTML5, diakses 13 Maret 2016). 